\title{
THE LEVEL OF THE EXCHANGE RATE AND THE BALANCE OF PAYMENTS, RELATIONS AND INFLUENCES
}

\author{
Associate Professor PhD Daniela Zăpodeanu, University of Oradea,danizapodeanu@yahoo.com \\ M Sc Student Mihai Cociuba, University of Oradea, cociuba@gmail.com
}

\begin{abstract}
The level of the exchange rate depends not only on the internal or external purchasing power, but also on other factors, and the element that synthesizes best the influence of these factors is the balance of payments, more precisely it's position, because the main influential factors of the exchange rate can be found synthesized in the balance of payments - evolution of imports and exports, capital flows under the form of direct investments or portfolio investments, etc. Because of the conception form of the balance of payments, it offers an easy way of reporting the economic course.
\end{abstract}

Key words: balance of payments, current account, capital account, exchange rate.

JEL codes: F40

The exchange rate reflects the position of the national economy in the background of the world economy. The level of the exchange rate represents an element of credibility of the national monetary system ${ }^{1}$, it is an important macroeconomic factor, as part of the monetary policy that is surveyed by the central bank, together with the monetary mass, the interest rate, the inflation rate; in Romania's case, as a result of joining the European Union and the preparation to accede to the euro area, predicted some time after 2014, the current account and also the capital account have been completely liberalized and the ERM II mechanisms are to be implemented, which makes following the stability and the level of the exchange rate, become increasingly important.

The exchange rate is influenced by a series of factors starting with imports and exports, interest rate, inflation rate; due to the fact that the number of influences concerning the exchange rate are varied and differs in intensities it is difficult to predict the exchange rate. The operation of predicting the currency rate of exchange is extremely difficult, because of the large amount of factors and the actors that take action on the foreign exchange market. Importers and exporters wish to minimize the fluctuation of the currency rate of exchange, associating this fluctuation to the notion of risk, exchange risk.

The main causes that make difficult predicting exchange rates are these ${ }^{2}$ :

- The time horizon for planning the exchange rate. The prediction can be made for a short period of time - that does not exceed seven days, for a medium term is considered the period between seven days and three months and for a long period of time is the prediction that is made for a tract of time of over three months.

- The impreciseness of prediction methods, grouped in 2 categories(but none of the methods offer exact answers, lacking the surety of a correct prediction):

- Methods based on technical analysis of relations between the evolution of the exchange rate and the dynamic of variables which determine it; these methods are based on methods of mathematical, econometrical modeling of past behavior of the evolution of exchange rate and the determined variables; it is then used the extrapolation of the

\footnotetext{
${ }^{1}$ Daniela Zăpodeanu, Monedă şi credit. Instituţii monetare şi de credit, Editura Universităţii din Oradea, 2003, pg.46

${ }^{2}$ Silviu Cerna, Economie monetară şi financiară internaţională, Editura Universităţii de Vest, Timişoara, 2006, pg.195
} 
determined relations regarding the past on the future(used for the prediction of short term exchange rates evolution).

- Methods based on economic models, are based on economic analysis - quantitative and qualitative - of relations relatively established that exist between the exchange rate and macroeconomic factors(inflation rate, interest rate, balance of the balance of payments, size of global income), used for long term predictions.

- Discreet variables, also two categories: economic variables and social-political variables.

- Economic variables essential in establishing the level of the exchange rate are: inflation rate, interest rate and the balance of the balance of payments.

The relationship between the exchange rate and the Inflation rate is explained in the "Purchasing power parity" theory, that offers a reference frame for understanding the evolution of the exchange rate on medium and long term and during periods of hyperinflation; the analysis and prediction of the exchange rate rely, in this case, on observation, processing and interpreting the data regarding the inflation rate and the inflation differential between different countries.

The interest rate influences the exchange rate through movements of capital attracted by higher out-puts in one country or another. The Purchasing power parity theory, expressed by J.M. Keynes, it is revealed how the forward rates of a currency depend on the interest rates corresponding to the respective term (differential of interest). The demand/sight exchange rate is considered as being an acceptable ${ }^{3}$ predictor of the short term exchange rate.

The balance of the trade balance and balance of payments are economic variables that influence the evolution of the exchange rate; an increase in the level of deficits determines the depreciation of the inland coin, while decreasing the deficits generates an appreciation. Due to the fact that the balance of payments includes the current account and the capital account, its influences on the exchange rate are complex and sometimes reversed, so if a trade deficit which theoretically should lead to depreciation can be covered by capital inputs in such a way that it generates an appreciation of the inland coin. The balance of payments represents an instrument important in explaining the evolution of the exchange rate and it is also an instrument important in predicting the evolution of the exchange rate.

- Social-political variables. The economic state of a country is influenced not only by pure economic factors but also by social and political factors like: political and social stability, administrative structure, the role which the state is playing in the economy, and also other psychological factors like trust in the national economy, investment climate, market expectations etc. It is understood that a slight change in the government of a certain country influences the level of the exchange rate, or a change in the perception of foreign investors; because the value of a currency also depends on the confidence economic actors have in it. The influence of these factors is a short term influence, because on the long term the influence diminishes, and no matter the perception, trusting or not trusting in a currency, time demonstrates through economic fundaments if the expectations have been real or not, which finally makes the level of the exchange rate determined by economic fundamental factors.

Predicting the exchange rate, due to the influence of numerous factors, is a difficult operation; according to modern studies that include hypothesis testing in "Monte Carlo" experiments and "random walk", it has been demonstrated that it is difficult to predict long term exchange rates, studies have showed that fundamental economic tendencies also influence the exchange rate.

\footnotetext{
${ }^{3}$ Silviu Cerna, Economie monetară şi financiară internațională, Editura Universității de Vest, Timişoara, 2006, pg. 198

${ }^{4}$ Jan Groen, Fundamentals based exchange rate prediction revisited, Bank of England, 2005, pg.9
} 
It results that the exchange rate level depends not only on the internal or external purchasing power but also on other factors, and the element that synthesizes best the influence of these factors is the balance of payments, more precisely it's position, because the main influential factors of the exchange rate can be found synthesized in the balance of payments - evolution of imports and exports, capital flows under the form of direct investments or portfolio investments, etc. Because of the conception form of the balance of payments, it offers an easy way of reporting the economic course, representing a synthesis at state level, which reflects all debts and claims of a state generated by commercial transactions with goods and/or services, also said, generated by capital movements 5 .

The balance of payments represents "a document, set by the competent state organs, which includes the systematical recording of the ensemble of returns and payments determined by real and financial transactions, from a certain period of time, of one country with the rest of the world - the global balance of payments - or with another country." 6

The balance of payments respects the principle of double entry accounting, using the following ratio:

$$
\begin{aligned}
& X+K_{i}=M+ K_{o} \quad \text { or } X @ M=K_{o} @ K_{i}, \\
& \mathrm{X}=\text { exports, } \\
& \mathrm{M}=\text { imports, } \\
& K_{i}=\text { increase of capital, } \\
& K_{o}=\text { decrease of capital. }
\end{aligned}
$$

The balance of payments is made out of the trade balance and the capital balance. So the imports, as in the national demand (internal) of foreign goods and the exports, meaning the foreign demand of aboriginal goods being submissive to the rules of the market, are sensible and fluctuate depending on the world prices and on the internal productivity and other factors; the currency demand for covering imports, and also the currency offer(from exports) influence the level of the exchange rate.

The current account is an extremly good indicator of the economic development, productivity and competitiveness on the World market and also for indicating certain unbalances in the economy. However the current account deficit does not always represent a negative aspect, it can appear as a result of ajustments through which the economy is passsing, a result of the development of certain new segment in detriment of the uncompetitive ones, or it can appear as a result of price fluctuations in exported goods; so the presence of a short term unbalance does not demonstrate economic problems, but the existence of a long term deficit shows severe economic problems and will surely generate an economic readjustment, by means of currency devaluation, or by means of structural reforms. Elements that compose the current account are:

- the trade balance, which reflects the value of imported and exported commercial goods whithout considering services;

- the balance of goods and services, this covers apart from imported and exported commercial goods, meaning the trade balance, other components: investment incomes, governmental services, transportation services, traveling and other services etc.

- the current account balance, contains moreover current transfers, these representing goods, services or income that do not involve payments in trade off.

\footnotetext{
${ }^{5}$ Codruța Maria Făt, Finanța internaționale, Editura Casa Cărții de Ştiință, Cluj-Napoca, 2007, pg. 160

${ }^{6}$ Kiritescu Costin, Dobrescu Emilian, Moneda-mica enciclopedie, Editura Enciclopedica, 1998, p.36.
} 


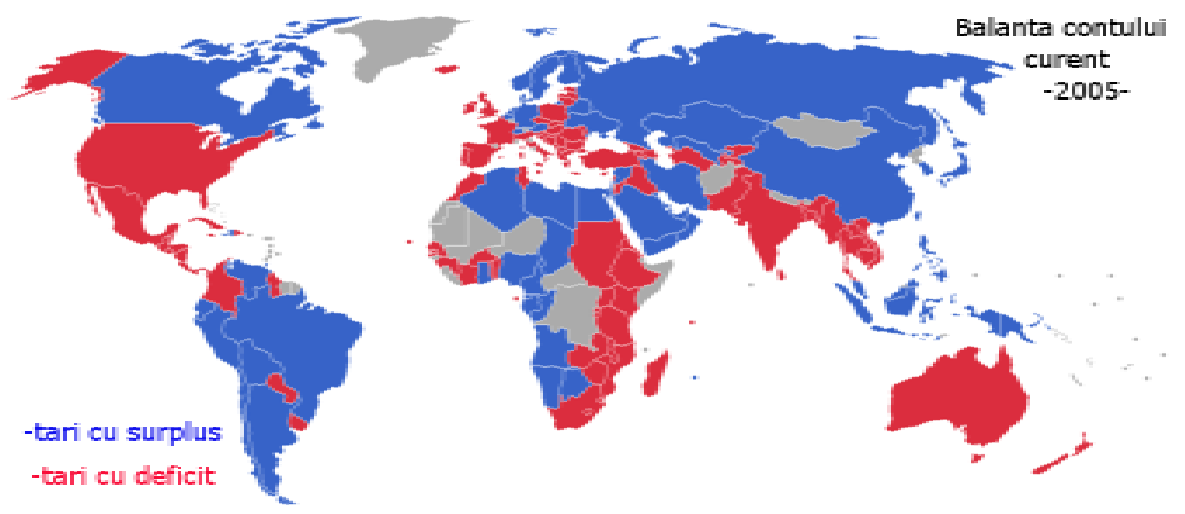

Fig no. 1. - Current account balance $2006^{7}$

Can be observed in figure 1, extremely suggestive the evolution of current account of serial countries, raised levels of deficits for USA (that generated a dramatically fall of dollar in front of euro and yen), and also strong economic development form Asia based especially on production. Can be also observed the mutations which who 21 century is confronting, by raising economical development level in emergences economies, especially in Asia.

The balance of capital movements reflects financial flows; a deficit for current account makes it necessary the existence of some capital flows under the shape of reducing foreign actives, or raising the foreign obligations for realizing the payments balance.

Currency international reserves are made by central banks and have as a final goal adjusting the transactions of a country with exterior; the level of currency reserves must cover the value of imports for 3-6 months. If after the transactions, the rest of the world records a surplus than the level of international reserves raises, contrary the deficit makes a reduction of reserves. Also can be use for intervention on exchange rate for avoiding sudden depreciation, in Romania one of the followed objective of BNR is stability of exchange rate. Big sums of capital coming from Asia, of exporting oil countries and other energetically products are invested in developed ${ }^{8}$ countries, especially USA in that case the deficit of current account reached the highest level.

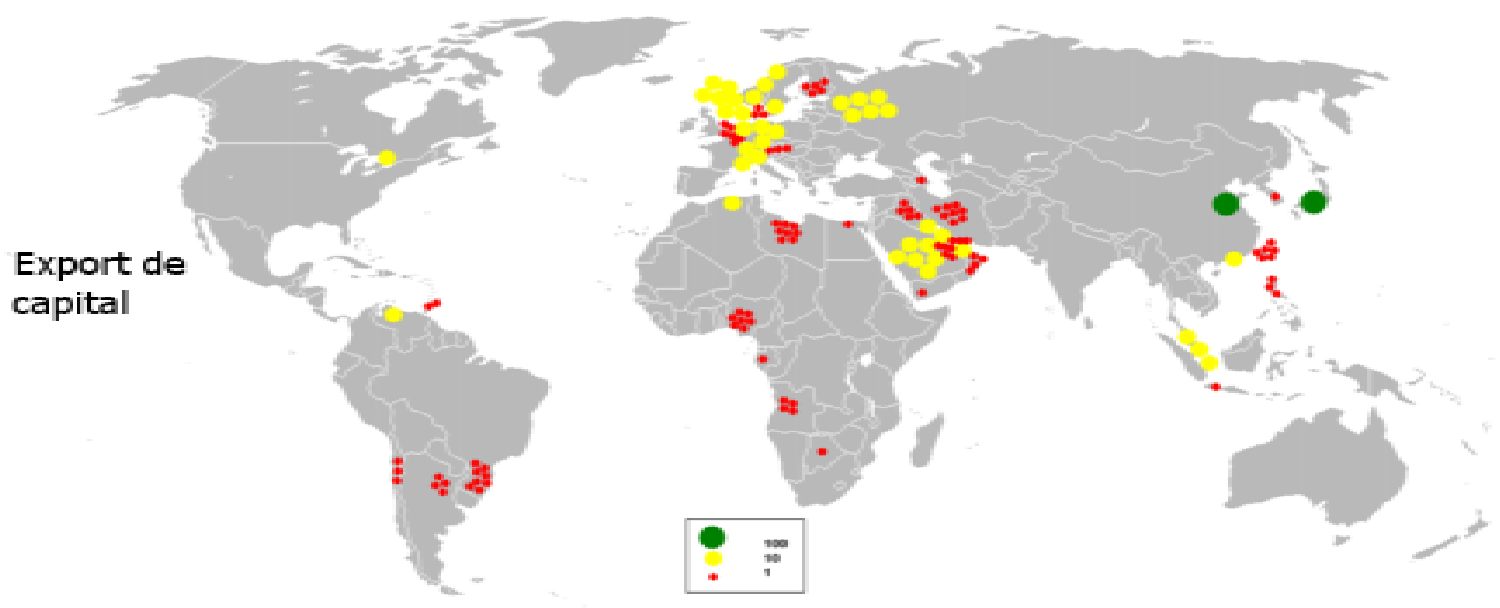

Fig no. 2. - Net capital exporting countries $-2006^{9}$

\footnotetext{
${ }^{7} \mathrm{http}$ //en.wikipedia.org/wiki/Balance_of_payments

${ }^{8}$ Acest proces culminând cu infiintarea asa numitelor " sovereign wealth funds", fonduri deținute de către statele în curs de dezvoltare (în special China, Rusia, țările arabe) şi care investesc preponderent în companii listate la bursele occidentale.

${ }^{9}$ http://en.wikipedia.org/wiki/Current_account
} 


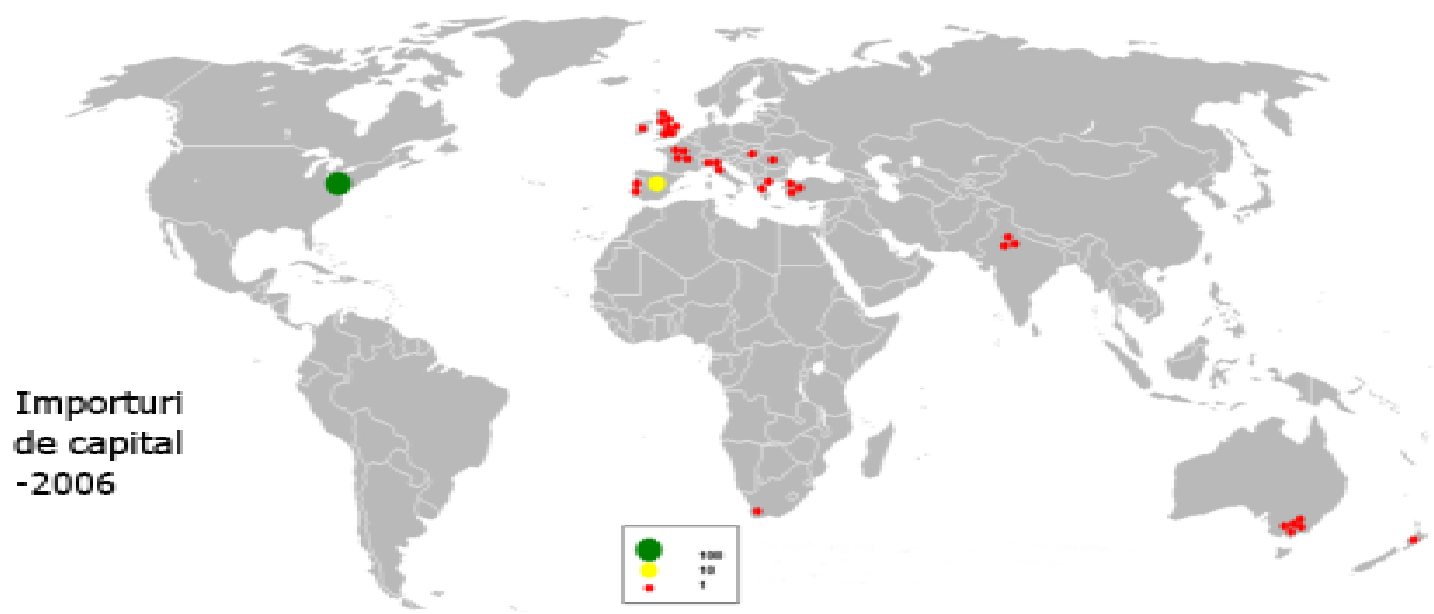

Fig no. 3. - Net capital importing countries $-2006^{10}$

It can be also observed financial surplus at international level: Japan (with well known role of international creditor) followed by China and countries that exports petrol and gas (Russia, Arabian Countries), an analysis of export - import of capital direction shows the functioning mode of relations at world economical level, covering the deficits of current account from developed countries through capital transfers from emergent countries - the main beneficiary of direct investments are developed countries followed by east European countries, new UE members that in "catch up" process are confronting economic restructuring and have raised levels of current account.

For understanding the mode in witch the permanents balance influence the exchange rate is necessary to present payments balance after FMI standards (model used by BNR in monthly reports)

Payments balance is formed from current account and capital and financial account.

\section{Curent account $(A+B+C)$}

A. goods and services

a. fob goods (export fob + import fob)

b. services: transport, travel, other services

B. Revenues - from work, direct investments, portfolio investments, other capital investments

C. Currents transfers - public administration, other sectors.

\section{2. capital and financial account $(A+B)$}

A. Capital account

a. capital transfers: public administration, others sectors

b. Acquisition/selling assets un- material un-financial

B. Financial account

a. direct investments of residents in other countries, of ne-residents in Romania

b. portfolio investments: assets and liabilities

c. financial derivates, assets and liabilities

\footnotetext{
${ }^{10} \mathrm{http}: / /$ en.wikipedia.org/wiki/Current_account
} 
d. other capital investments

- Assets: loans and credits on short and long terms, commercial and financial, cash and deposits; other short and long term assets

- liabilities: credits and loans from FMI; credits and loans on short and long terms commercial and financial, cash and deposits; other short and long term assets

e. Reserve assert of BNR Active de

\section{Errors and omissions (net)}

Negative balance of current account, meaning a deficit of current payments balance, is financed through direct investments, portfolio investments, and capital transfers and less usage of currency reserve of central bank.

Analyzing payment balance of Romania at the and of year 2007 can be observed the raising of deficit level with $66 \%$, in the same time that direct investments level felled with $23 \%$, and covering the current account deficit was made in principally with external credits. The year 2007 showed am embittering of main, the raised deficit of current account and the way of financing this in front of last year, all corroborate with low foreign direct investments and strong entrance of speculative capitals in Romanian economy. Can be observed that the level of devises in falling that can be explained by passing from a appreciation trend of Leu to a depreciation one, in2007 BNR intervening to limit the strong fluctuation of exchange rate, the trend id of embittering of main indices; having in sight the economic development of Romania and the recent integration in UE is necessary a limitation of current account deficit, reducing it at a sustainable level through macroeconomic politics. From analyzing financial sources for current account deficit (table) can be observed a falling of foreign investments level form 8723 in 2006 to 7069 million of euro in 2007, in the same time that current account deficit jumps from 10156 in 2006 to 16872 million of euro in2007, such a strong raise of deficit is realized through a strong fall of exchange rate for euro from3.4 at the beginning of 2007 to 3.11 in 2 of July, and at the end of year the exchange rate to be 3.6

Table no. 1

\begin{tabular}{|c|c|c|}
\hline Simplified model of payments balance ${ }^{\| 1}$ & 2006 & 2007 \\
\hline A. current account deficit & -10156 & -16872 \\
\hline \multicolumn{3}{|l|}{ B. financing sources } \\
\hline 1. capital transfers & -24 & 849 \\
\hline 2. Direct investments & 8723 & 7069 \\
\hline 3 portfolio investments and financial derivates & -280 & -15 \\
\hline 4. other investments & 6271 & 13324 \\
\hline $\begin{array}{l}\text { 5. reserve assets BNR in convertible devise (- shows raise, } \\
+ \text { shows falling }\end{array}$ & -5158 & -4505 \\
\hline $\begin{array}{l}\text { 6. other positions (transit accounts, clearing accounts, } \\
\text { errors and omissions) }\end{array}$ & 624 & 150 \\
\hline
\end{tabular}

Negative evolution and un-sustainable of current account deficit makes that in second part year 2007 leu to lose the ground earned, euro level will raise tempering the deficit, and starting

\footnotetext{
${ }^{11}$ Source: www.bnro.ro, Buletin lunar 12/2007
} 
with year 2008 export raise rate index will excel the imports one, all these showing that you cannot maintain a currency in continuous re-valorization on a extern deficit in expanse.

Last 2 years were characterized by continues raises of commercial deficit and higher and higher levels of current account deficit raises serious problems for our country. To control the high levels of commercial deficit is necessary to take in first place measures that actions over imports and demand, these could be :

- exchange rate leu/euro under-valued, an under-valued currency will make the imports less attractive and will generate exports growth

- payroll raises under the productivity level to maintain inflationist threat under control is necessary that productivity level to exceed payroll raises, budgetary sector being most exposed to payroll raises economic un-justified

- Limitations of indebted, as we shown before credit raise the demand that will be covered especially with imports and only after with national production generates the raise of commercial balance deficit.

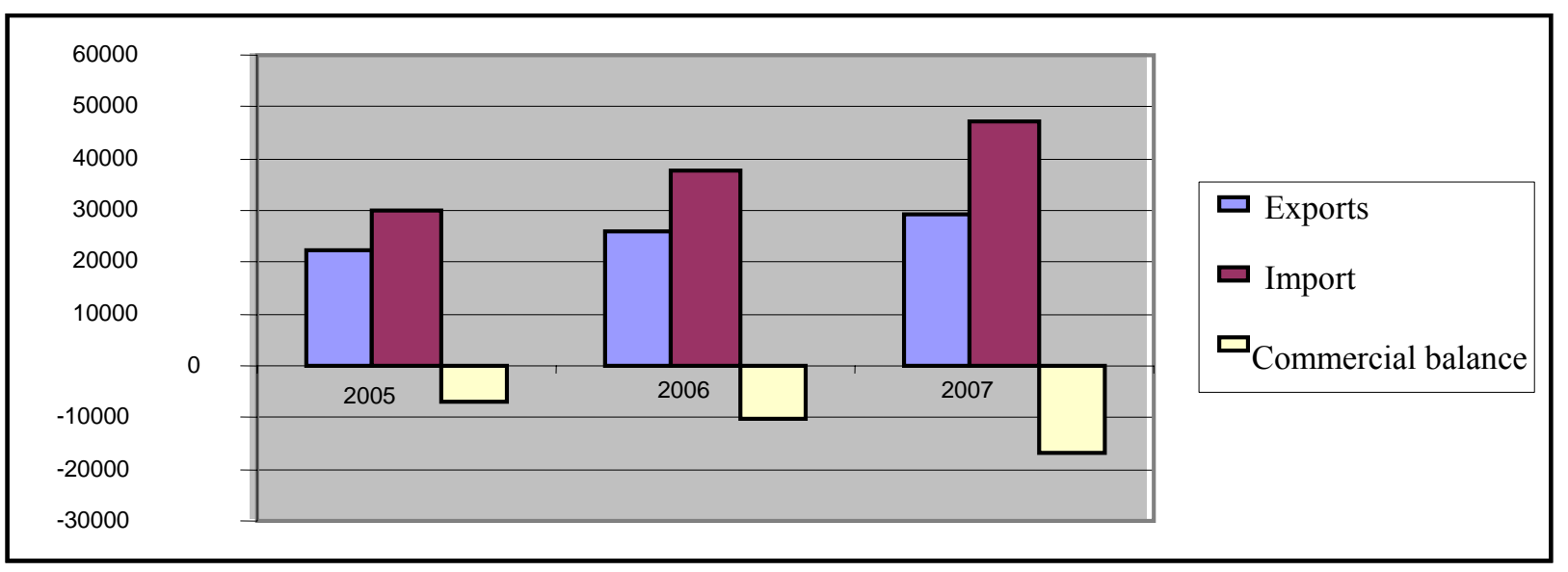

Fig. no. 4

Econometric analysis realized over relation from exchange rate and commercial balance components shows that our country is passing through a period of intense transformations, strong growth of demand (from necessity of reaching a higher life level) corroborated with raising foreign investments level (especially after joining UE) influenced strongly exchange rate in past years making that national currency to appreciate continuously. Is said that market has always right, and currency market through its liquidity and its profoundness is close more and more of "perfect market" concept, but when raised levels of deficit goes together with appreciation of national currency the problem raised is how much time will continue the process, and when will be over what will be happening, will be o "sudden landing" of national economy or just a moment of respire before growing again. National Bank of Romania through specific instruments (interest rate, minimal obligatory reserves and even national reserves) must be preoccupied by a economic growth sustained and at levels closed to maximum potential of economy, and most important sustainable especially having in sight years 2012-2014 as a period of acceleration of Exchanging European Mechanism and after entering in euro zone.

\section{References:}

1. Zăpodeanu Daniela - Monedă şi credit. Instituții monetare şi de credit, Editura Universității din Oradea, 2003.

2. Cerna Silviu - Economie monetară şi financiară internațională, Editura Universității de Vest, Timişoara, 2006. 
3. Groen Jan - Fundamentals based exchange rate prediction revisited, Bank of England, 2005.

4. Făt Codruța Maria - Finanțe internaționale, Editura Casa Cărții de Ştiință, Cluj-Napoca, 2007.

5. Kiritescu Costin, Dobrescu Emilian - Moneda-mica enciclopedie, Editura Enciclopedica, 1998.

6. http://en.wikipedia.org/wiki/Current_account

7. http://en.wikipedia.org/wiki/Balance_of_payments

8. www.bnro.ro, Buletin lunar 12/2007 